\title{
Feeding wet distillers grains plus solubles with and without a direct-fed microbial to determine performance, carcass characteristics, and fecal shedding of Escherichia coli 0157:H7 in feedlot heifers ${ }^{1}$
}

\author{
B. K. Wilson, ${ }^{* 2}$ B. P. Holland, ${ }^{3}$ D. L. Step, M. E. Jacob, $\dagger^{3}$ D. L. VanOverbeke, * \\ C. J. Richards, * T. G. Nagaraja, $\dagger$ and C. R. Krehbiel* \\ *Department of Animal Science, Oklahoma State University, Stillwater 74078; \\ $\uparrow$ Department of Diagnostic Medicine/Pathobiology, Kansas State University, Manhattan 66506; and \\ †Department of Veterinary Clinical Sciences, Oklahoma State University, Stillwater 74078
}

\begin{abstract}
The inclusion of wet distillers grains plus solubles (WDGS) in feedlot diets has become a common practice in many regions of the United States due to the expanded production of byproducts and fluctuating corn prices related to ethanol production and other factors. In addition, societal concerns over the continued use of antimicrobials in agriculture production combined with an enhanced interest in disease and pathogen prevention in the food supply have led to an increased interest in use of direct-fed microbials (DFM) in growing and finishing cattle. Direct-fed microbials have been shown to improve ADG and feed efficiency, alter ruminal fermentation, and decrease fecal shedding of potential harmful pathogens in feedlot cattle in some experiments. The objective of this experiment was to evaluate the effects of WDGS inclusion with or without a DFM containing Lactobacillus acidophilus $\left(1 \times 10^{6} \mathrm{cfu} \cdot\right.$ heif$\left.\mathrm{er}^{-1} \cdot \mathrm{d}^{-1}\right)$ combined with Propionibacterium freudenreichii $\left(1 \times 10^{9} \mathrm{cfu} \cdot\right.$ heifer $\left.^{-1} \cdot \mathrm{d}^{-1}\right)$ on the performance, carcass characteristics, and Escherichia coli $\mathrm{O} 157: \mathrm{H} 7$ shedding in feedlot heifers. In early August, 288 crossbred heifers (initial BW $=295 \pm 28 \mathrm{~kg}$ ) were assigned to 1 of 4 treatments (12 pens per treatment; 6 heifers per
\end{abstract}

pen) in a randomized complete block design with a $2 \times$ 2 factorial arrangement of treatments. Body weights and fecal grab samples were obtained at approximately 28-d intervals throughout the experiment. Across the feeding period, heifers fed 30\% WDGS tended $(P=0.09)$ to have greater $\mathrm{ADG}$ and had greater carcass-adjusted ADG $(P=0.05)$ compared with heifers fed dry-rolled corn (DRC). Dry matter intake was not affected $(P=$ $0.65)$ by diet, although carcass-adjusted G:F tended $(P=$ $0.10)$ to be improved for heifers fed WDGS. Heifers fed $30 \%$ WDGS tended $(P \leq 0.10)$ to have greater fat thickness at the 12th rib, lower marbling scores, and higher yield grades. The inclusion of L. acidophilus combined with $P$. freudenreichii in the diet had no effect $(P>0.10)$ on performance or carcass merit in the present experiment. The incidence of E. coli $\mathrm{O} 157: \mathrm{H} 7$ throughout the experiment was low, with only 18 positive samples across all sampling periods. Neither WDGS inclusion nor the inclusion of $L$. acidophilus combined with $P$. freudenreichii in the diet had any effect $(P>0.10)$ on $E$. coli $\mathrm{O} 157: \mathrm{H} 7$ shedding in this experiment. Feeding 30\% WDGS to feedlot heifers improved animal performance compared to the DRC-based control diet.

Key words: beef cattle, direct-fed microbials, Lactobacillus acidophilus, Propionibacterium freudenreichii, wet distillers grains plus solubles

\footnotetext{
${ }^{1}$ All research was conducted at the Willard Sparks Beef Research Center in Stillwater, OK, except fecal sample analysis for the Escherichia coli shedding component of this experiment which was conducted at Kansas State University. The authors wish to thank the employees of the Willard Sparks Beef Research Center for assisting with this experiment. This project was funded by Nutrition Physiology Company, LLC, and the Oklahoma Agricultural Experiment Station.
}

\footnotetext{
${ }^{2}$ Corresponding author: the.blake.wilson@okstate.edu

${ }^{3}$ Present Addresses: B. P. Holland; Cactus Feeders, Amarillo, TX 79106. M. E. Jacob; Department of Population Health and Pathobiology, North Carolina State University, Raleigh 27695.

Received July 27, 2015.

Accepted October 24, 2015.
} 


\section{INTRODUCTION}

Expanded ethanol production has contributed to fluctuating corn prices and increased the availability of byproducts, including wet distillers grains plus solubles (WDGS), that can be fed to ruminants. The inclusion of WDGS in feedlot diets has become a common practice due to numerous benefits associated with the feeding of WDGS, including the potential for reduced ration costs and improved cattle performance (Klopfenstein et al., 2008). However, some research has indicated there is a connection between feeding distillers grains and increased Escherichia coli shedding in feedlot cattle (Jacob et al., 2008; Varel et al., 2008).

Current public perception is that there is a need for sufficient disease and pathogen prevention while simultaneously enhancing performance and reducing antimicrobial use in feedlots. As a result, directfed microbials (DFM) have received much consideration as they are a source of live, naturally occurring microorganisms (Yoon and Stern, 1995). In a review of DFM utilization consisting of 10,900,504 cattle in 73,870 feedyards, steers and heifers had $1.9 \%$ and $1.4 \%$ improved $\mathrm{ADG}$, respectively, when receiving a DFM (McDonald et al., 2005). Additionally, studies have shown that feeding a DFM may reduce the fecal shedding of E. coli O157:H7 (Elam et al., 2003; Peterson et al., 2007). Data suggest that DFM have the potential to improve production efficiency in cattle and decrease the shedding of potential harmful pathogens (Krehbiel et al., 2003; Wilson and Krehbiel, 2012). We hypothesized that feeding 30\% WDGS and a DFM containing Lactobacillus acidophilus and Propionibacterium freudenreichii would improve cattle performance. Additionally, we hypothesized that feeding the DFM might reduce $E$. coli shedding. The objective of this experiment was to evaluate the effects of the inclusion of $30 \%$ WDGS with or without a DFM on the performance, carcass characteristics, and E. coli $\mathrm{O} 157: \mathrm{H} 7$ shedding of feedlot heifers fed a high-concentrate diet.

\section{MATERIALS AND METHODS}

All procedures for the present experiment were approved by the Oklahoma State University Institutional Animal Care and Use Committee (Animal Care and Use Protocol AG-07-15).

\section{Experimental Design and Animals}

In late July, 288 crossbred heifers (BW at arrival $=295 \pm 28 \mathrm{~kg}$ ) were delivered to the Willard Sparks Beef Research Center at Oklahoma State University. On arrival at the feed yard, heifers were individually weighed and a uniquely numbered ear tag was placed in the left ear of each calf. On the morning following arrival, heifers were individually weighed, vaccinated for protection against infectious bovine herpes virus-1, bovine viral diarrhea virus (types I and II), bovine parainfluenza-3, and bovine respiratory syncytial virus (Vista 5 SQ, Intervet; Merck Animal Health, Summit, NJ), Clostridium chauvoei, septicum, novyi, sordellii, and perfringens types $\mathrm{C}$ and $\mathrm{D}$ (Vision 7 with SPUR; Merck Animal Health, Summit, NJ), treated for control of external and internal parasites (IvomecPlus injectable; Merial, Duluth, GA) and implanted with Revalor IH (Merck Animal Health, Summit, NJ).

The experiment was initiated in early August and continued through the fall and winter months. Initial BW were obtained by using the average BW of the heifers on consecutive days. The heifers were then blocked by initial BW into 12 weight blocks. Within block, heifers were randomly assigned to 4 pens (12 pens per treatment; 6 heifers per pen). Heifers were reimplanted based on BW with Revalor H (Merck Animal Health, Summit, NJ) on d 56 (6 heaviest weight blocks) or d 84 (6 lightest weight blocks).

\section{Treatments and Diets}

Heifers were assigned to 1 of 4 treatments in a randomized complete block design with a $2 \times 2$ factorial arrangement of treatments. Heifers were assigned to either a diet containing 30\% WDGS or a dry-rolled corn (DRC)-based control diet. The WDGS utilized in this experiment were purchased and shipped to the feedlot from East Kansas Agri-Energy, Garnett, KS. Within the dietary treatments, heifers were assigned to a DFM treatment that was color-coded and blinded to research personnel until the conclusion of the experiment. The DFM product utilized was a commercially available DFM containing L. acidophilus and P. freudenreichii (Bovamine; Nutrition Physiology Company, LLC, Guymon, OK). The treatments consisted of the DFM, containing $1 \times 10^{6} \mathrm{cfu} \cdot$ heifer $^{-1} \cdot \mathrm{d}^{-1}$ of L. acidophilus combined with $1 \times 10^{9} \mathrm{cfu} \cdot$ heifer $^{-1} \cdot \mathrm{d}^{-1}$ of $P$. freudenreichii or the control treatment containing no DFM.

The diets were fed from d 1 through finish (133, 167 , or $188 \mathrm{~d}$ on feed, DOF). Cattle were fed ad libitum twice daily at $0600 \mathrm{~h}$ and $1300 \mathrm{~h}$. The WDGS finishing diet contained 58.0\% DRC and 30.0\% WDGS and was formulated to meet or exceed NRC (2000) nutrient requirements (Table 1). The DRC finishing diet contained $80.75 \%$ DRC and was formulated to meet or exceed NRC (2000) nutrient requirements (Table 1). Monensin (Rumensin; Elanco, Greenfield, IN) was fed at a rate of $33 \mathrm{mg} / \mathrm{kg}$ of diet. Tylosin (Ty- 
Table 1. Composition of experimental diets on a dry matter (DM) basis

\begin{tabular}{|c|c|c|c|c|c|c|c|c|}
\hline \multirow[b]{2}{*}{ Ingredient $(\% \mathrm{DM})^{1}$} & \multicolumn{4}{|c|}{ Wet distillers grains plus solubles } & \multicolumn{4}{|c|}{ Dry-rolled corn } \\
\hline & Receiving & Step 1 & Step 2 & Finisher & Receiving & Step 1 & Step 2 & Finisher \\
\hline Dry rolled corn & 44.00 & 49.00 & 54.00 & 58.00 & 52.75 & 62.50 & 72.25 & 80.75 \\
\hline Wet distillers grains & 15.00 & 20.00 & 25.00 & 30.00 & 0.00 & 0.00 & 0.00 & 0.00 \\
\hline Prairie hay & 17.50 & 12.50 & 10.00 & 6.00 & 17.50 & 12.50 & 10.00 & 6.00 \\
\hline Alfalfa hay & 17.50 & 12.50 & 5.00 & 0.00 & 17.50 & 12.50 & 5.00 & 0.00 \\
\hline Fat & 0.00 & 0.00 & 0.00 & 0.00 & 0.25 & 0.50 & 0.75 & 1.25 \\
\hline Liquid supplement ${ }^{2}$ & 0.00 & 0.00 & 0.00 & 0.00 & 6.00 & 6.00 & 6.00 & 6.00 \\
\hline Dry supplement $176^{3}$ & 6.00 & 6.00 & 6.00 & 6.00 & 0.00 & 0.00 & 0.00 & 0.00 \\
\hline Dry supplement $175^{4}$ & 0.00 & 0.00 & 0.00 & 0.00 & 6.00 & 6.00 & 6.00 & 6.00 \\
\hline \multicolumn{9}{|l|}{ Nutrient (DM basis) ${ }^{5}$} \\
\hline $\mathrm{NE}_{\mathrm{m}}, \mathrm{Mcal} / \mathrm{kg}$ & 1.90 & 1.92 & 1.97 & 2.04 & 1.85 & 1.87 & 1.97 & 2.08 \\
\hline $\mathrm{NE}_{\mathrm{g}}, \mathrm{Mcal} / \mathrm{kg}$ & 1.17 & 1.19 & 1.26 & 1.31 & 1.12 & 1.16 & 1.25 & 1.37 \\
\hline TDN, $\%$ & 75.20 & 75.77 & 78.02 & 80.05 & 73.75 & 74.60 & 77.74 & 81.70 \\
\hline Crude protein, $\%$ & 15.55 & 15.87 & 16.16 & 15.51 & 17.10 & 15.88 & 14.44 & 12.68 \\
\hline Crude fat, $\%$ & 5.37 & 5.76 & 6.56 & 6.71 & 4.46 & 4.53 & 5.19 & 6.67 \\
\hline NDF, $\%$ & 26.17 & 26.22 & 24.21 & 18.95 & 24.07 & 24.42 & 17.43 & 12.29 \\
\hline $\mathrm{ADF}, \%$ & 14.36 & 14.09 & 11.79 & 8.71 & 15.18 & 13.93 & 9.99 & 5.96 \\
\hline Calcium, \% & 0.85 & 0.82 & 0.77 & 0.54 & 0.92 & 0.73 & 0.66 & 0.38 \\
\hline Phosphorus, \% & 0.39 & 0.43 & 0.50 & 0.45 & 0.37 & 0.33 & 0.35 & 0.32 \\
\hline Potassium, \% & 1.12 & 1.18 & 0.98 & 0.75 & 1.30 & 1.28 & 1.08 & 0.77 \\
\hline Sulfur, \% & 0.21 & 0.20 & 0.20 & 0.22 & 0.25 & 0.23 & 0.22 & 0.18 \\
\hline
\end{tabular}

${ }^{1}$ All values are presented on a (DM) basis.

${ }^{2}$ Liquid supplement was Synergy 19-14 (Westway Feed Products, New Orleans, LA).

${ }^{3}$ Dry supplement 176 contained (\% DM): $58.19 \%$ ground corn, $2.50 \%$ cane molasses, $0.17 \%$ potassium chloride, $27.5 \%$ limestone, $5.33 \%$ urea, $4.17 \%$ salt, $0.08 \%$ manganous oxide, $0.22 \%$ zinc sulfate, $1.17 \%$ magnesium oxide, $0.10 \%$ copper sulfate, $0.05 \%$ vitamin A $(30,000 \mathrm{IU} / \mathrm{g}), 0.04 \%$ vitamin $\mathrm{E}(50 \%)$, 0.31\% Rumensin 80 (Elanco Animal Health, Indianapolis, IN), 0.19\% Tylan 40 (Elanco Animal Health, Indianapolis, IN).

${ }^{4}$ Dry supplement 175 contained (\% DM): $32.45 \%$ soybean meal, $15 \%$ cottonseed meal, $2.50 \%$ cane molasses, $4.17 \%$ potassium chloride, $24.17 \%$ limestone, $3.33 \%$ dicalcium phosphate, $10.67 \%$ urea, $4.17 \%$ salt, $0.09 \%$ manganous oxide, $0.29 \%$ zinc sulfate, $2.5 \%$ magnesium oxide, $0.08 \%$ copper sulfate, $0.05 \%$ vitamin A (30,000 IU/g), 0.04\% vitamin E (50\%), 0.31\% Rumensin 80 (Elanco Animal Health, Indianapolis, IN), $0.19 \%$ Tylan 40 (Elanco Animal Health, Indianapolis, IN).

${ }^{5}$ Feed samples were analyzed for nutrient composition by an independent laboratory (SDK Laboratories, Hutchinson, KS).

lan; Elanco, Greenfield, IN) was fed at a rate of $10 \mathrm{mg} /$ $\mathrm{kg}$ of diet. Heifers were gradually adapted to their final treatment diet using 3 step-up diets shown in Table 1. The 3 step-up diets were fed for $7 \mathrm{~d}$ each.

Experimental treatments were provided via a dry ground corn premix containing the experimental cultures and fed at the rate of $227 \mathrm{~g}$ per head daily top dressed onto the total mixed ration and mixed in the complete diet in each individual pen's feed bunk. Control treatments received equal amounts of the dry ground corn premix containing no DFM fed at the same rate per head daily top dressed onto the total mixed ration and mixed in the complete diet in each individual pen's feed bunk. Before mixing, the DFM and the control (equal amount of ground corn containing no DFM) were stored in a freezer in color-coded individual packets. The individual premixes for each DFM treatment were initially mixed with $1,814 \mathrm{~g}$ of ground corn using 2 separate KitchenAid mixers (5 QT Artisan Mixer Model 5SM150PS; KitchenAid, St. Joseph, MI). This premix was divided in half to 907 $\mathrm{g}$ and then mixed with $15.4 \mathrm{~kg}$ of ground corn in 2 separate cement mixers (Red Lion Big Cat; Monarch Industries, Winnipeg, Manitoba, Canada). This was repeated with the second half of the initial premix and $15.4 \mathrm{~kg}$ of ground corn yielding a total of $16.3 \mathrm{~kg}$ of total premix per treatment. Mixers were dedicated to each individual DFM treatment throughout the experiment to prevent any cross contamination of treatments. One thousand three hundred and sixty-one grams of the premix were then weighed into individually numbered $3.8 \mathrm{~L}$ color-coded plastic containers assigned to the appropriate treatment pen. Contents of the appropriate container were mixed directly into the feed in each bunk after feed was delivered to pens of cattle assigned to that treatment.

Feed refused was weighed on each weigh day and as needed (e.g., following inclement weather) for DM determination. In addition, diet samples were collected, and DM content of diets and dietary ingredients were determined. Diet samples and refused feed were dried in a forced-air oven $\left(60^{\circ} \mathrm{C}\right)$ to determine sample DM. In addition, diet samples were shipped off to a commercial laboratory (SDK Laboratories, Hutchin- 
son, KS) for nutrient analysis. Samples were analyzed for crude protein (AOAC, 1996), ether extract, ADF (Goering and Van Soest, 1970), NDF, calcium, phosphorus, potassium, sulfur, and ADF calculated TDN, NEg, and NEm (Table 1).

\section{Body Weights}

Interim unshrunk BW was determined by weighing pens and individual animals on d 28, 56, 84, 119, and immediately before shipping for harvest (shipped in 3 separate groups). Pen weights were used for statistical analysis as pen was the experimental unit. For calculating ADG, weights taken on all days were shrunk $4 \%$. The heaviest pens ( 8 pens) were harvested after 133 DOF, the medium weight pens (20 pens) were harvested after $167 \mathrm{DOF}$, and the lightest weight pens (20 pens) were harvested after 188 DOF. Carcass-adjusted BW was calculated by taking the individual HCW for each animal divided by the average dressing percentage for each of 3 harvest groups (light, medium, and heavy). Carcass-adjusted BW was then used to calculate carcass-adjusted ADG and carcass-adjusted G:F.

\section{Carcass Data and Liver Scores}

The heifers were harvested at Cargill Meat Solutions, Dodge City, KS, in 3 separate groups (light, medium, and heavy). Trained personnel from Oklahoma State University along with Cargill personnel obtained all carcass measurements. Measurements included hot carcass weight (HCW), liver abscess score (data collected by Cargill personnel), longissimus muscle area and marbling score of the split lean surface at the 12th/13th rib interface, percentage of kidney, pelvic, and heart (KPH) fat, fat thickness opposite the split lean surface between the 12th and 13th rib, USDA Yield Grade, and USDA Quality Grade. Liver abscess scores were recorded on a scale of 0 to 6 , with $0=$ no abscesses, $1=\mathrm{A}-, 2=\mathrm{A}, 3=\mathrm{A}+, 4=$ telangiectasis, 5 $=$ distoma (fluke damage), and $6=$ fecal contamination that occurred at slaughter.

\section{Escherichia coli $0157: H 7$ Shedding}

Fecal samples obtained from each animal per rectum on d $0,28,56,84$, and 119 were kneaded, and approximately $1 \mathrm{~g}$ of fecal material was placed in $9 \mathrm{~mL}$ of Gram Negative (GN) broth supplemented with cefixime $(0.05 \mathrm{mg} / \mathrm{L})$, cefsulodin $(10.0 \mathrm{mg} / \mathrm{L})$, and vancomycin $(8.0 \mathrm{mg} / \mathrm{L}$; GNccv). Samples were vortexed for $1 \mathrm{~min}$ and incubated for $5 \mathrm{~h}$ at $37^{\circ} \mathrm{C}$. Immunomagnetic separation (IMS; Dynal, Inc.) was performed following enrichment, and $50 \mu \mathrm{L}$ of product was plat- ed onto sorbitol MacConkey agar supplemented with cefixime $(50 \mathrm{ng} / \mathrm{mL})$ and potassium tellurite $(2.5 \mu \mathrm{g} /$ mL; CT-SMAC). Plates were incubated overnight at $37^{\circ} \mathrm{C}$ and up to 6 sorbitol negative colonies from each sample were picked and streaked onto blood agar plates. Blood agar plates were incubated overnight at $37^{\circ} \mathrm{C}$ and colonies were tested for indole production, the presence of the $\mathrm{O} 157$ antigen using latex agglutination, and confirmation of species with PCR analysis of eae, fliC, stx 1, stx2, hylA, and $r f b \mathrm{E}$ virulence genes.

A semiquantitative method was employed to categorize fecal culture positive cattle into low shedders $\left(<5 \times 10^{4} \mathrm{cfu} / \mathrm{g}\right)$ and high shedders $\left(>5 \times 10^{4} \mathrm{cfu} / \mathrm{g}\right.$; Sanderson et al., 2007). Briefly, a swab of 1:10 diluted fecal suspension in GNccv broth before enrichment was plated onto a CT-SMAC plate and incubated for 16 to $18 \mathrm{~h}$ at $37^{\circ} \mathrm{C}$. From direct streaked CT-SMAC plates, up to 6 sorbitol negative colonies were transferred to a blood agar plate and evaluated for indole production, latex agglutination for the O157:H7 antigen, and PCR. This direct streaking of pre-enriched fecal sample identifies samples with E. coli $\mathrm{O} 157: \mathrm{H} 7$ concentrations > $10^{3} \mathrm{cfu} / \mathrm{g}$ with sensitivity and specificity estimates of $83 \%$ and $92 \%$, respectively (Sanderson et al., 2007).

\section{Calculations and Statistical Analysis}

Data for BW, ADG, DMI, G:F, and parametric carcass characteristics were analyzed as a randomized complete block design using the PROC MIXED procedure of SAS Release 9.1.3 (SAS Inst. Inc., Cary, NC). Nonparametric USDA Quality Grade data were transformed using the Freedman's test by listing the percentage of Choice and Select for each pen within a block, and then were analyzed as the normally distributed data as above. Pen was the experimental unit. The model statement included treatment, and the random statement included block.

For the $E$. coli shedding data, initially the data were modeled in the GLIMMIX procedure of SAS with collection day, diet, and DFM included as fixed effects. Pen was included as a random effect. Samples that were missing or duplicate sample numbers on a collection day were included as missing values in the data set. Two animals that only had 1 observation were removed from the data set entirely. Analysis could not be completed on these models, likely because of low prevalence. Therefore, the FREQ procedure of SAS was used to run a chi-square analysis of data (ignoring pen and collection day) with diet and DFM as categories. 
Table 2. Effects of wet distillers grains plus solubles with and without a direct-fed microbial containing Lactobacillus acidophilus and Propionibacterium freudenreichii on body weight and average daily gain

\begin{tabular}{|c|c|c|c|c|c|c|c|c|}
\hline \multirow[b]{2}{*}{ Item } & \multicolumn{2}{|c|}{ WDGS $^{1}$} & \multicolumn{2}{|c|}{$\mathrm{DRC}^{1}$} & \multirow[b]{2}{*}{ SEM } & \multicolumn{3}{|c|}{$P$-value } \\
\hline & Control $^{2}$ & $\mathrm{DFM}^{2}$ & Control $^{2}$ & $\mathrm{DFM}^{2}$ & & Diet & DFM & Diet $\times$ DFM \\
\hline \multicolumn{9}{|l|}{$\overline{\mathrm{BW}}, \mathrm{kg}$} \\
\hline Initial & 303 & 303 & 303 & 303 & 20.5 & 0.98 & 0.99 & 0.98 \\
\hline $\mathrm{d} 28$ & 338 & 333 & 333 & 336 & 18.9 & 0.78 & 0.76 & 0.26 \\
\hline d 56 & 381 & 377 & 376 & 373 & 18.7 & 0.16 & 0.24 & 0.82 \\
\hline d 84 & 426 & 424 & 419 & 415 & 20.7 & 0.06 & 0.41 & 0.80 \\
\hline d 119 & 479 & 479 & 475 & 471 & 21.4 & 0.27 & 0.69 & 0.69 \\
\hline Finish $^{3}$ & 516 & 517 & 513 & 503 & 13.8 & 0.14 & 0.43 & 0.35 \\
\hline Carcass adjusted ${ }^{4}$ & 518 & 519 & 513 & 505 & 13.1 & 0.13 & 0.56 & 0.48 \\
\hline \multicolumn{9}{|l|}{ Average daily gain, $\mathrm{kg}$} \\
\hline d $1-28$ & 1.07 & 0.90 & 0.86 & 1.04 & 0.06 & 0.57 & 0.89 & 0.01 \\
\hline d 29- 56 & 1.61 & 1.64 & 1.61 & 1.39 & 0.09 & 0.15 & 0.26 & 0.15 \\
\hline d $57-84$ & 1.59 & 1.67 & 1.53 & 1.48 & 0.09 & 0.09 & 0.90 & 0.40 \\
\hline d 85- 119 & 1.55 & 1.62 & 1.65 & 1.66 & 0.07 & 0.38 & 0.59 & 0.67 \\
\hline d $120-$ finish $^{3}$ & 0.97 & 0.99 & 0.96 & 0.86 & 0.19 & 0.25 & 0.57 & 0.35 \\
\hline d $1-$ finish $^{3}$ & 1.31 & 1.31 & 1.28 & 1.24 & 0.09 & 0.08 & 0.53 & 0.40 \\
\hline Carcass adjusted ${ }^{4}$ & 1.34 & 1.34 & 1.30 & 1.26 & 0.08 & 0.05 & 0.45 & 0.43 \\
\hline
\end{tabular}

${ }^{1}$ WDGS $=$ Wet distillers grains plus solubles. DRC $=$ Dry-rolled corn.

${ }^{2}$ Control treatments contained no direct-fed microbial. Direct-fed microbial (DFM) treatments contained $1 \times 10^{6} \mathrm{cfu} \cdot \mathrm{heifer}^{-1} \cdot \mathrm{d}^{-1}$ of Lactobacillus acidophilus combined with $1 \times 10^{9} \mathrm{cfu} \cdot$ heifer $^{-1} \cdot \mathrm{d}^{-1}$ of Propionibacterium freudenreichii (Bovamine; Nutrition Physiology Company., Guymon, OK).

${ }^{3}$ Heifers were harvested on d 133 (Heavy block), d 167 (Medium block), or d 188 (Light block).

${ }^{4}$ Carcass-adjusted BW calculated as HCW/average dressing percent for each harvest block.

\section{RESULTS AND DISCUSSION}

Feedlot performance data from across the feeding period are presented in Tables 2 and 3. Two interactions were observed during the first $28 \mathrm{~d}$ of the experiment. There was a WDGS $\times$ DFM interaction for both ADG $(P=0.01$; Table 2$)$ and $\mathrm{G}: \mathrm{F}(P=0.04$; Table 3$)$ from $\mathrm{d}$ 1 to 28 . Average daily gain was greater for heifers fed the $30 \%$ WDGS diet without the DFM and the DRC diet with the DFM compared to the 30\% WDGS diet with the DFM and the DRC diet without the DFM from $\mathrm{d} 1$ to 28 (Table 2). The same trend was observed in G:F from d 1 to 28 with the $30 \%$ WDGS diet without the DFM and the DRC diet with the DFM having improved G:F compared to the $30 \%$ WDGS diet with the DFM and the DRC diet without the DFM (Table 3). No other interactions were observed throughout the experiment.

Heifers receiving 30\% WDGS in their diet had numerically improved performance compared to heifers receiving the DRC control diet. The BW of heifers receiving 30\% WDGS tended $(P=0.06)$ to be heavier on $\mathrm{d} 84$ compared with heifers receiving the DRC control diet. Final BW was not different for heifers fed $30 \%$ WDGS compared to heifers receiving the DRC control diet. However, heifers fed 30\% WDGS had $1.7 \%$ higher average final $\mathrm{BW}(P=0.14)$. In addition, heifers fed the $30 \%$ WDGS tended $(P=0.08)$ to have greater ADG and had greater carcass-adjusted ADG $(P=0.05)$ compared with heifers fed DRC. Gain:feed was not different for heifers fed 30\% WDGS compared to heifers fed the DRC-based diet $(P=0.19)$, but was numerically improved for heifers receiving $30 \%$ WDGS. Carcass-adjusted G:F also tended $(P=$ $0.10)$ to be improved for heifers fed WDGS. We calculated the feeding value of the WDGS in the diet as described by Klopfenstein et al. (2008). This resulted in a feeding value of $110 \%$ for the WDGS compared to the DRC. Average DMI was not affected $(P=0.65)$ by diet, although heifers fed the $30 \%$ WDGS had greater DMI $(P=0.01)$ from d 29 to 56.

The improved performance for heifers receiving WDGS are consistent with previous research. It is well established that WDGS can improve cattle performance when compared to corn-based control diets (Klopfenstein et al., 2008). Wet distillers grains plus solubles-based diets have been shown to have greater feeding values and improved G:F when compared to corn-based control diets (Vander Pol et al., 2006; Klopfenstein et al., 2008; Corrigan et al., 2009). Research has demonstrated that increasing WDGS quadratically affects ADG and DMI with both ADG and DMI being maximized at $20 \%$ to $30 \%$ of the diet on a DM basis (Klopfenstein et al., 2008). In diets containing WDGS, G:F tends to be more linear and is maximized at higher inclusion levels, up to $30 \%$ to $50 \%$ of diet DM (Klopfenstein et al., 2008). The meta-analysis suggests that the optimum level of wet distillers grains to include in diets to maximize cattle 
Table 3. Effects of wet distillers grains plus solubles with and without a direct-fed microbial containing Lactobacillus acidophilus and Propionibacterium freudenreichii on dry matter intake and gain:feed

\begin{tabular}{|c|c|c|c|c|c|c|c|c|}
\hline \multirow[b]{2}{*}{ Item } & \multicolumn{2}{|c|}{ WDGS $^{1}$} & \multicolumn{2}{|c|}{$\mathrm{DRC}^{1}$} & \multirow[b]{2}{*}{ SEM } & \multicolumn{3}{|c|}{$P$-value } \\
\hline & Control $^{2}$ & $\mathrm{DFM}^{2}$ & Control $^{2}$ & $\mathrm{DFM}^{2}$ & & Diet & DFM & Diet $\times$ DFM \\
\hline \multicolumn{9}{|l|}{ Dry matter intake, $\mathrm{kg}$} \\
\hline d $1-28$ & 7.87 & 7.78 & 7.65 & 7.89 & 0.48 & 0.69 & 0.57 & 0.21 \\
\hline d 29- 56 & 8.91 & 8.94 & 8.44 & 8.47 & 0.43 & 0.01 & 0.84 & 0.98 \\
\hline d $57-84$ & 9.10 & 9.09 & 8.94 & 8.75 & 0.47 & 0.24 & 0.63 & 0.68 \\
\hline d 85- 119 & 8.93 & 9.13 & 9.34 & 9.17 & 0.40 & 0.26 & 0.92 & 0.35 \\
\hline d 120- finish ${ }^{3}$ & 8.15 & 8.54 & 8.52 & 8.32 & 0.49 & 0.69 & 0.61 & 0.12 \\
\hline d 1 - finish ${ }^{3}$ & 8.56 & 8.70 & 8.59 & 8.53 & 0.46 & 0.65 & 0.82 & 0.53 \\
\hline \multicolumn{9}{|l|}{ Gain:Feed } \\
\hline d $1-28$ & 0.136 & 0.116 & 0.114 & 0.131 & 0.014 & 0.70 & 0.89 & 0.04 \\
\hline d 29- 56 & 0.183 & 0.186 & 0.194 & 0.166 & 0.014 & 0.68 & 0.24 & 0.15 \\
\hline d $57-84$ & 0.176 & 0.183 & 0.172 & 0.170 & 0.007 & 0.21 & 0.68 & 0.48 \\
\hline d 85- 119 & 0.175 & 0.180 & 0.178 & 0.183 & 0.008 & 0.70 & 0.54 & 1.00 \\
\hline d 120- finish ${ }^{3}$ & 0.117 & 0.115 & 0.111 & 0.101 & 0.016 & 0.16 & 0.41 & 0.58 \\
\hline d 1 - finish ${ }^{3}$ & 0.150 & 0.149 & 0.147 & 0.143 & 0.003 & 0.19 & 0.39 & 0.65 \\
\hline Carcass adjusted ${ }^{4}$ & 0.155 & 0.154 & 0.152 & 0.147 & 0.003 & 0.10 & 0.32 & 0.63 \\
\hline
\end{tabular}

${ }^{1}$ WDGS $=$ Wet distillers grains plus solubles. DRC $=$ Dry-rolled corn.

${ }^{2}$ Control treatments contained no direct-fed microbial. Direct-fed microbial (DFM) treatments contained $1 \times 10^{6} \mathrm{cfu}^{\cdot} \cdot$ heifer $^{-1} \cdot \mathrm{d}^{-1}$ of Lactobacillus acidophilus combined with $1 \times 10^{9} \mathrm{cfu} \cdot$ heifer $^{-1} \cdot \mathrm{d}^{-1}$ of Propionibacterium freudenreichii (Bovamine; Nutrition Physiology Company., Guymon, OK).

${ }^{3}$ Heifers were harvested on d 133 (Heavy block), d 167 (Medium block), or d 188 (Light block).

${ }^{4}$ Carcass-adjusted BW calculated as HCW/average dressing percent for each harvest block.

performance lies somewhere between $20 \%$ and $30 \%$ for DRC-based diets (Klopfenstein et al., 2008).

Klopfenstein et al. (2008) reported the feeding values for WDGS between $126 \%$ and $145 \%$ of the feeding value of corn. These feeding values are higher than the calculated feeding value from the present experiment. However, in the present experiment, diets were formulated to be isocaloric where added fat was included in the DRC-based control diet. Many of the experiments with feeding values for WDGS included in the meta-analysis by Klopfenstein et al. (2008) did not attempt to formulate diets that were isocaloric. This should be considered when evaluating the feeding value of WDGS in diets as distillers grains contain a greater percentage of fat than ingredients being replaced in the diet. To get an accurate feeding value comparison, the diets should be balanced for fat content to avoid large differences in the energy content of diets being compared. This method results in reduced feeding values for diets containing WDGS and a more realistic comparison to corn-based diets.

May et al. (2010) conducted an experiment where both corn and sorghum WDGS were fed in steamflaked corn (SFC)-based diets. Varying amounts of additional fat were added to the diets in an attempt to formulate diets that were isocaloric (May et al., 2010). No differences were observed in calculated $\mathrm{NE}_{\mathrm{m}}$ and $\mathrm{NE}_{\mathrm{g}}$ values for the average of diets containing WDGS compared to the SFC control diet (May et al., 2010).
In contrast to the current experiment, May et al. (2010) reported that final BW, ADG, and carcass-adjusted G:F were less for cattle fed WDGS compared to cattle fed the control diet (May et al., 2010).

Buttrey et al. (2013) conducted an experiment where $0 \%$ WDGS or $35 \%$ WDGS was fed in DRCbased or SFC-based diets. Similar to the current experiment, additional fat was added to the diets containing 0\% WDGS in an attempt to formulate isocaloric diets. Similar to the current experiment, Buttrey et al. (2013) reported improvements in G:F and carcassadjusted G:F for cattle fed WDGS. However, Buttrey et al. (2013) stated that the inclusion of 35\% WDGS did not affect final BW or ADG. These studies by May et al. (2010) and Buttrey et al. (2013) emphasize the importance of balancing diets for fat content when evaluating the energy value of dietary ingredients.

In the present experiment, the inclusion of the DFM product did not improve animal performance. It should be noted that the improvements in ADG and G:F reported in the literature when DFM are fed are generally small $(<5 \%)$ and thus difficult to detect in small pen research settings (Krehbiel et al., 2003; Wilson and Krehbiel, 2012). However, most population data and large pen commercial experiments concerning DFM supplementation would indicate a slight improvement in performance.

In the Vetlife survey, it was demonstrated that cattle receiving a DFM product exhibited improved per- 
Table 4. Effects of wet distillers grains plus solubles with and without a direct-fed microbial containing Lactobacillus acidophilus and Propionibacterium freudenreichii on carcass characteristics

\begin{tabular}{|c|c|c|c|c|c|c|c|c|}
\hline \multirow[b]{2}{*}{ Item } & \multicolumn{2}{|c|}{ WDGS $^{1}$} & \multicolumn{2}{|c|}{$\mathrm{DRC}^{1}$} & \multirow[b]{2}{*}{ SEM } & \multicolumn{3}{|c|}{$P$-value } \\
\hline & Control $^{2}$ & $\mathrm{DFM}^{2}$ & Control $^{2}$ & $\mathrm{DFM}^{2}$ & & Diet & DFM & Diet $\times$ DFM \\
\hline $\mathrm{HCW}, \mathrm{kg}$ & 333 & 333 & 329 & 324 & 7.08 & 0.13 & 0.56 & 0.47 \\
\hline Dressing percentage & 64.3 & 64.5 & 64.2 & 64.2 & 0.00 & 0.53 & 0.81 & 0.87 \\
\hline Ribeye area, $\mathrm{cm}^{2}$ & 82.2 & 80.7 & 83.5 & 82.0 & 2.69 & 0.28 & 0.23 & 0.98 \\
\hline 12 th-rib fat, cm & 1.61 & 1.65 & 1.54 & 1.46 & 0.09 & 0.10 & 0.79 & 0.47 \\
\hline KPH, \% & 3.19 & 3.30 & 3.09 & 3.37 & 0.14 & 0.93 & 0.19 & 0.55 \\
\hline Marbling score ${ }^{3}$ & 404 & 411 & 418 & 431 & 14.0 & 0.09 & 0.33 & 0.75 \\
\hline Prime and Choice, $\%$ & 56.6 & 49.3 & 56.6 & 56.3 & 9.78 & 0.64 & 0.61 & 0.64 \\
\hline Yield grade & 2.93 & 3.08 & 2.74 & 2.79 & 0.38 & 0.07 & 0.41 & 0.68 \\
\hline Liver score $^{4}$ & 0.19 & 0.35 & 0.57 & 0.28 & 0.14 & 0.29 & 0.63 & 0.11 \\
\hline
\end{tabular}

${ }^{1}$ WDGS $=$ Wet distillers grains plus solubles. DRC $=$ Dry-rolled corn.

${ }^{2}$ Control treatments contained no direct-fed microbial. Direct-fed microbial (DFM) treatments contained $1 \times 10^{6} \mathrm{cfu}^{\cdot} \mathrm{heifer}^{-1} \cdot \mathrm{d}^{-1}$ of Lactobacillus acidophilus combined with $1 \times 10^{9} \mathrm{cfu} \cdot$ heifer $^{-1} \cdot \mathrm{d}^{-1}$ of Propionibacterium freudenreichii (Bovamine; Nutrition Physiology Company., Guymon, OK).

${ }^{3}$ Marbling scores: $400=$ Small $^{00}, 500=$ Modest $^{00}$.

${ }^{4}$ Liver Score: 0 = no abscesses, $1=\mathrm{A}-, 2$ =A, 3 = A+, 4 = telangiectasis, $5=$ distoma (fluke damage), and $6=$ fecal contamination.

formance (McDonald et al., 2005). Steers receiving a DFM had $1.9 \%$ greater ADG and a $1.9 \%$ improvement in feed conversion when compared to control steers (McDonald et al., 2005). Heifers fed a DFM had 1.4\% greater $\mathrm{ADG}$ and a $3.9 \%$ improvement on feed conversion compared to control heifers (McDonald et al., 2005). It should be noted that while the Vetlife survey compared the performance and efficiency of cattle that received a DFM product to cattle that did not receive a DFM product, specific DFM dosages and spp. were not considered (McDonald et al., 2005). To make direct comparisons between experiments, DFM spp. and dosages should certainly be considered. However, these population data collected on an excess of 10,000,000 animals certainly have value and merit mentioning when discussing the effects of DFM on animal performance.

Cull et al. (2015) evaluated the efficacy of the same dosage of L. acidophilus and P. freudenreichii used in the current experiment on the performance and carcass characteristics of cattle in a commercial feedlot setting. Cattle receiving the combination DFM had increased total BW gains and improved G:F compared to cattle not receiving the DFM product. McPeake et al. (2002) examined data from 6 research trials consisting of 1,249 steers to determine the effects of L. acidophilus combined with a single dose of $P$. freudenreichii on feedlot performance. When steers receiving the DFM were contrasted against steers not receiving the DFM, the DFM supplemented steers had greater final live weights, overall ADG, and carcass-adjusted ADG (McPeake et al., 2002). Steers receiving the DFM also tended to have greater overall DMI compared to steers not receiving the DFM (McPeake et al., 2002). While there is evidence that bacterial DFM improve perfor- mance, results have been inconsistent (Krehbiel et al., 2003; McAllister et al., 2011; Wilson and Krehbiel, 2012). This inconsistent response is evidenced by another experiment that examined the effects of 2 strains of $L$. acidophilus combined with a single dose of $P$. freudenreichii in which Elam et al. (2003) determined that the DFM did not affect animal performance.

The carcass merit data are presented in Table 4. There were no differences $(P \geq 0.13)$ among treatments for $\mathrm{HCW}$, dressing percentage, longissimus muscle area, KPH, USDA Quality Grade, or liver abscess score. However, heifers fed 30\% WDGS tended to have greater fat thickness at the 12th rib, lower marbling scores, and higher yield grades $(P=0.10$, $P=0.09$, and $P=0.07$, respectively). These results are consistent with previous research which suggests there are undesirable changes in carcass composition in cattle fed diets with high levels of WDGS (Reinhardt et al., 2007; Klopfenstein et al., 2008). Klopfenstein et al. (2008) demonstrated that 12th rib fat thickness and yield grade responded quadratically to increasing WDGS in the diet. In contrast, Buttrey et al. (2013) reported no difference in 12th rib fat thickness, marbling score, or yield grade for cattle fed $35 \%$ WDGS. In an additional meta-analysis, Reinhardt et al. (2007) showed that diets containing low levels of distillers grains (16\% and lower) increased marbling score, while diets containing high levels of distillers grains (33\% and higher) decreased marbling score. Corrigan et al. (2009) suggested that in DRC diets the inclusion of up to $27.5 \%$ WDGS increased marbling score which contradicts what we observed in this experiment. Impacts of WDGS on carcass merit and characteristics have demonstrated mixed results. 
The inclusion of L. acidophilus combined with $P$. freudenreichii in the diet had no effect $(P \geq 0.19)$ on carcass merit in the present experiment. This would be in agreement with data from other DFM research trials which suggest that feeding a DFM will not significantly impact dressing percentage, yield grade, quality grade, or any other carcass traits, with the exception of potentially increasing hot carcass weight (McPeake et al., 2002; Krehbiel et al., 2003; Vasconcelos et al., 2008).

Neither WDGS inclusion nor the inclusion of $L$. acidophilus combined with $P$. freudenreichii in the diet had any effect $(P>0.10)$ on $E$. coli shedding in this experiment. Results for the $E$. coli shedding data were unable to be sufficiently evaluated across pens and collection days due to the low overall prevalence of $E$. coli $\mathrm{O} 157: \mathrm{H} 7$ throughout the entire experiment, and as a result, the E. coli data are not presented. Escherichia coli was observed in only 1.2\% (18 of 1,415 samples) of the fecal samples. The low prevalence observed in this experiment was potentially due to the majority of the experiment taking place in the fall and winter. Escherichia coli prevalence is greatest in the summer, with the highest incidence of $E$. coli shedding by cattle taking place in the summer months (Greenquist et al., 2005; Loneragan and Brashears 2005; Callaway et al., 2009). Higher shedder prevalence was also low, $0.21 \%$ (3 of 1,415 samples). All samples that were classified as coming from high shedders were also positive after enrichment.

Cull et al. (2012) evaluated the efficacy of the same dosage of L. acidophilus and P. freudenreichii used in the current experiment on $E$. coli shedding in a commercial feedlot setting. The overall prevalence of E. coli $\mathrm{O} 157: \mathrm{H} 7$ was much higher $(31.7 \%$ of samples were positive for E. coli) in the experiment by Cull et al. (2012). This elevated incidence of $E$. coli could be the result of the timing of the experiment (summer), the commercial environment, the greater number of cattle enrolled in the experiment, or other factors. However, Cull et al. (2012) stated that the supplementation of the combination DFM had no effect on $E$. coli shedding or the prevalence of high shedders $\left(>10^{4} \mathrm{cfu} / \mathrm{g}\right)$, which would be in agreement with the current experiment. While feeding $1 \times 10^{6} \mathrm{cfu} \cdot$ animal $^{-1} \cdot \mathrm{d}^{-1}$ of L. acidophilus does not appear to impact E. coli shedding, some experiments have shown that feeding a DFM containing $1 \times 10^{9} \mathrm{cfu} \cdot$ animal $^{-1} \cdot \mathrm{d}^{-1}$ of L. acidophilus may reduce the fecal shedding of $E$. coli $\mathrm{O} 157: \mathrm{H} 7$ (Elam et al., 2003; Peterson et al., 2007).

\section{Conclusions}

Wet distillers grains plus solubles can be an effective protein and energy source for feedlot cattle by replacing traditional ration ingredients when fed at appropriate levels in feedlot diets. This experiment suggests that WDGS has a greater feeding value than DRC due to the improved performance in heifers receiving the diet containing 30\% WDGS. While there is evidence that DFM improve cattle performance, results have been inconsistent. We observed that the inclusion of a DFM containing $1 \times 10^{6} \mathrm{cfu} \cdot$ heifer $^{-1} \cdot \mathrm{d}^{-1}$ of $L$. acidophilus combined with $1 \times 10^{9} \mathrm{cfu} \cdot$ heifer $^{-1} \cdot \mathrm{d}^{-1}$ of $P$. freudenreichii had no effect on animal performance. While some research suggests that WDGS and DFM can impact $E$. coli shedding, the prevalence of $E$. coli $\mathrm{O} 157: \mathrm{H} 7$ throughout the experiment was too low to make any inferences. Feeding 30\% WDGS to feedlot heifers improved animal performance compared to the DRC-based control diet.

\section{LITERATURE CITED}

AOAC. 1996. Official methods of analysis. 16th ed. Assoc. Off. Anal. Chem., Arlington, VA.

Buttrey, E. K., K. H. Jenkins, J. B. Lewis, S. B. Smith, R. K. Miller, T. E. Lawrence, F. T. McCollum, I. I. I. P. J. Pinedo, N. A. Cole, and J. C. MacDonald. 2013. Effects of 35\% corn wet distillers grains plus solubles in steam-flaked and dry-rolled corn-based finishing diets on animal performance, carcass characteristics, beef fatty acid composition, and sensory attributes. J. Anim. Sci. 91:1850-1865.

Callaway, T. R., M. A. Carr, T. S. Edrington, R. C. Anderson, and D. J. Nisbet. 2009. Diet, Escherichia coli O157:H7, and cattle: A review after 10 years. Curr. Issues Mol. Biol. 11:67-80.

Corrigan, M. E., G. E. Erickson, T. J. Klopfenstein, M. K. Luebbe, K. J. Vander Pol, N. F. Meyer, C. D. Buckner, S. J. Vanness, and K. J. Hanford. 2009. Effect of corn processing method and corn wet distillers grains plus solubles inclusion level in finishing steers. J. Anim. Sci. 87:3351-3362.

Cull, C. A., Z. D. Paddock, T. G. Nagaraja, N. M. Bello, and A. H. Babcock. 2012. Efficacy of a vaccine and a direct-fed microbial against fecal shedding of Escherichia coli $\mathrm{O} 157: \mathrm{H} 7$ in a randomized pen-level field trial of commercial feedlot cattle. Vaccine 30:6210-6215.

Cull, C. A., D. G. Renter, N. M. Bello, S. E. Ives, and A. H. Babcock. 2015. Performance and carcass characteristics of commercial feedlot cattle from a study of vaccine and direct-fed microbial effects on Escherichia coli O157:H7 fecal shedding. J. Anim. Sci. 93:3144-3151.

Elam, N. A., J. F. Gleghorn, J. D. Rivera, M. L. Galyean, P. J. Defoor, M. M. Brashears, and S. M. Younts-Dahl. 2003. Effects of live cultures of Lactobacillus acidophilus (strains NP45 and NP51) and Propionibacterium freudenreichii on performance, carcass, and intestinal characteristics, and Escherichia coli strain O157 shedding of finishing beef steers. J. Anim. Sci. 81:2686-2698.

Goering, H. K., and P. J. Van Soest. 1970. Forage fiber analyses. Agric. Handbook No. 379, ARS, USDA, Washington, DC.

Greenquist, M. A., J. S. Drouillard, J. M. Sargeant, B. E. Depenbusch, X. Shi, K. F. Lechtenberg, and T. G. Nagaraja. 2005. Comparison of rectoanal mucosal swab cultures and fecal cultures for determining prevalence of Escherichia coli O157:H7 in feedlot cattle. Appl. Environ. Microbiol. 71:6431-6433. 
Jacob, M. E., J. T. Fox, J. S. Drouillard, D. G. Renter, and T. G. Nagaraja. 2008. Effects of dried distillers' grains on fecal prevalence and growth of Escherichia coli $\mathrm{O} 157$ in batch culture fermentations from cattle. Appl. Environ. Microbiol. 74:38-43.

Klopfenstein, T. J., G. E. Erickson, and V. R. Bremer. 2008. Board invited review: Use of distillers by-products in the beef cattle feeding industry. J. Anim. Sci. 86:1223-1231.

Krehbiel, C. R., S. R. Rust, G. Zhang, and S. E. Gilliland. 2003. Bacterial direct fed microbials in ruminant diets: Performance response and mode of action. J. Anim. Sci. 81(E-Suppl. 2):E120-E132.

Loneragan, G. H., and M. M. Brashears. 2005. Pre-harvest interventions to reduce carriage of $E$. coli $\mathrm{O} 157$ by harvest-ready feedlot cattle. Meat Sci. 71:72-78.

May, M. L., J. C. DeClerck, M. J. Quinn, N. DiLorenzo, J. Leibovich, D. R. Smith, K. E. Hales, and M. L. Galyean. 2010. Corn or sorghum wet distillers grains with solubles in combination with steam-flaked corn: Feedlot cattle performance, carcass characteristics, and apparent total tract digestibility. J. Anim. Sci. 88:2433-2443.

McAllister, T. A., K. A. Beauchemin, A. Y. Alazzeh, J. Baah, R. M. Teather, and K. Stanford. 2011. Review: The use of direct fed microbials to mitigate pathogens and enhance production in cattle. Can. J. Anim. Sci. 91:193-211.

McDonald, A., P. Andersen, P. Defoor, and R. Botts. 2005. DFMs improve health, performance of cattle. Feedstuffs 77:12-13.

McPeake, C. A., C. S. Abney, K. Kizilkaya, M. L. Galyean, A. H. Trenkle, J. J. Wagner, D. R. Ware, and S. R. Rust. 2002. Effects of direct-fed microbial products on feedlot performance and carcass characteristics of feedlot steers. Proc. Plains Nutr. Council, Texas A\&M Agric. Exp. Sta. Publ. No. AREC 02-02 p. 133 (Abstr.)

NRC. 2000. Nutrient requirements of beef cattle: Update 2000. 7th Ed. Natl. Acad. Press. Washington, DC.
Peterson, R. E., T. J. Klopfenstein, G. E. Erickson, J. Folmer, and S. Hinkley. 2007. Effect of Lactobacillus acidophilus strain NP51 on Escherichia coli $\mathrm{O} 157: \mathrm{H} 7$ fecal shedding and finishing performance in beef feedlot cattle. J. Food Prot. 70(2):287-291.

Reinhardt, C. D., A. DiConstanzo, and G. Milliken. 2007. Distiller's by-products alter carcass fat distribution of feedlot cattle. J. Anim. Sci. 85(Suppl. 2):132. (Abstr.)

Sanderson, M. W., S. Sreerama, and T. G. Nagaraja. 2007. Sensitivity of direct plating for detection of high levels of E. coli $\mathrm{O} 157: \mathrm{H} 7$ in bovine fecal samples. Curr. Microbiol. 55(2):158-161.

Vander Pol, K. J., G. E. Erickson, T. J. Klopfenstein, M. A. Greenquist, and T. Robb. 2006. Effect of dietary inclusion of wet distillers grains on feedlot performance of finishing cattle and energy value relative to corn. Nebraska Beef Cattle Report. MP88-A:51-53.

Vasconcelos, J. T., N. A. Elam, M. M. Brashears, and M. L. Galyean. 2008. Effects of increasing dose of live cultures of Lactobacillus acidophilus (Strain NP 51) combined with a single dose of Propionibacterium freudenreichii (Strain NP 24) on performance and carcass characteristics of finishing beef steers. J. Anim. Sci. 86:756-762.

Varel, V. H., J. E. Wells, E. D. Berry, M. J. Spiehs, D. N. Miller, C. L. Ferrell, S. D. Shackelford, and M. Koohmaraie. 2008. Odorant production and persistence of Escherichia coli in manure slurries from cattle fed zero, twenty, forty, or sixty percent wet distillers grains with solubles. J. Anim. Sci. 93:3144-3151.

Wilson, B. K., and C. R. Krehbiel. 2012. Current and future status of practical applications: Beef cattle. In: T. R. Callaway and S. C. Ricke, editors, Direct-fed microbials and prebiotics for animals. Springer Science \& Business Media, New York. p. 137-153.

Yoon, I. K., and M. D. Stern. 1995. Influence of direct-fed microbials on ruminal microbial fermentation and performance of ruminants: A review. Asian-Australas. J. Anim. Sci. 8:533-555. 